\title{
"The impact of ethnocentrism and its antecedents on cultural heritage tourism along the Silk Road"
}

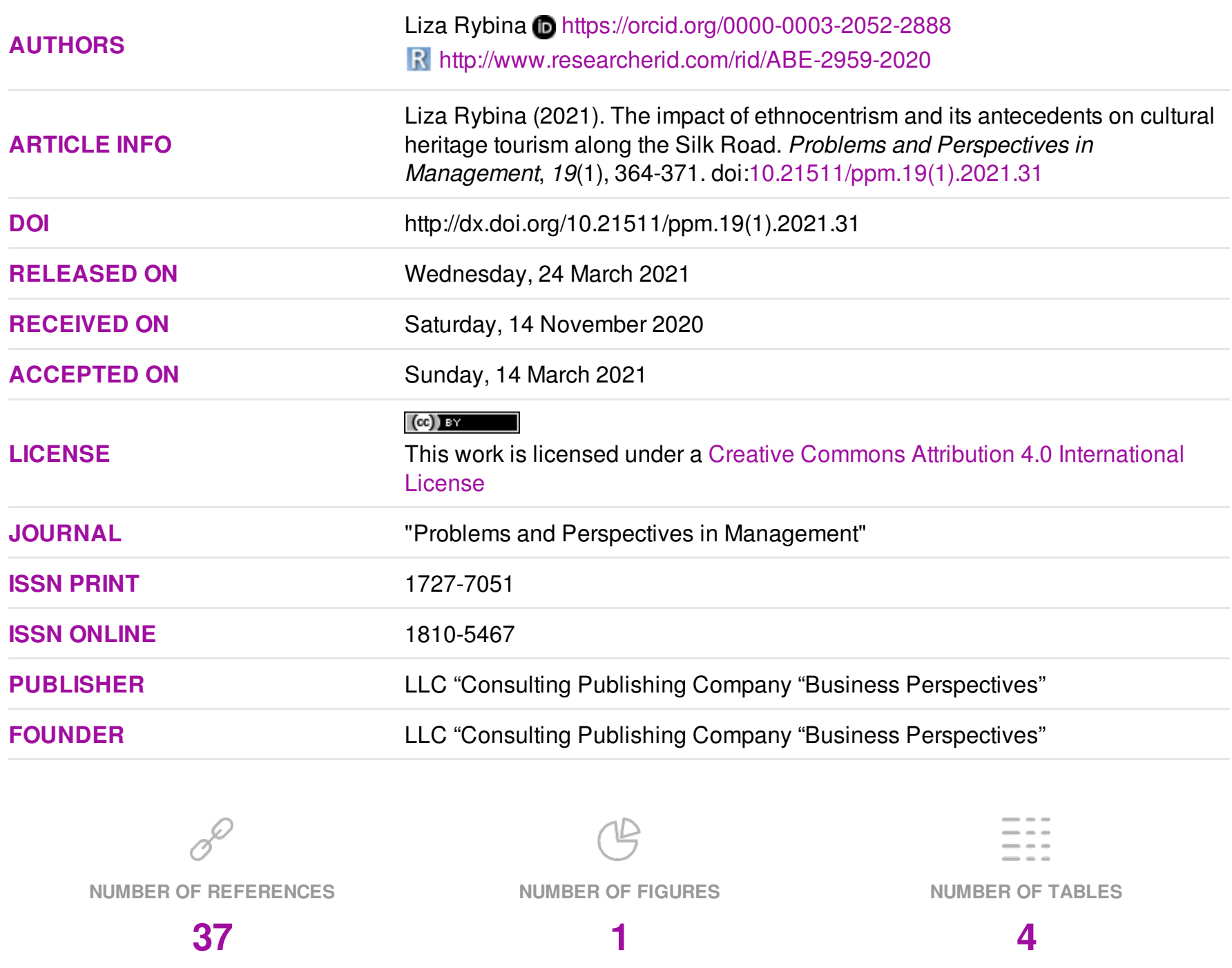

(C) The author(s) 2021. This publication is an open access article. 


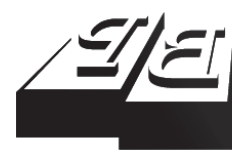

\section{BUSINESS PERSPECTIVES}

O

LLC "CPC "Business Perspectives" Hryhorii Skovoroda lane, 10, Sumy, 40022, Ukraine www.businessperspectives.org

Received on: $14^{\text {th }}$ of November, 2020 Accepted on: 14 ${ }^{\text {th }}$ of March, 2021 Published on: $24^{\text {th }}$ of March, 2021

๑ Liza Rybina, 2021

Liza Rybina, DBA, Assistant Professor, Department of Management and Marketing, KIMEP University, Almaty, Kazakhstan.

\section{THE IMPACT OF ETHNOCENTRISM AND ITS ANTECEDENTS ON CULTURAL HERITAGE TOURISM ALONG THE SILK ROAD}

\begin{abstract}
The Great Silk Road offers a high potential for the cultural and heritage tourism development as more travelers are interested in the past and culture of the others. The aim of this study is to examine the relationship between patriotism, cultural openness, ethnocentrism and outcomes of tourism in the context of the Central Asia. The study uses a quantitative approach. A survey method was applied to collect data from 146 local residents living in the heritage tourism areas. The analysis included descriptive statistics, confirmatory factor analysis (CFA), and structural equation modeling (SEM) analysis. The obtained results demonstrate that patriotism had a significant positive impact on ethnocentrism of local residents, while cultural openness had a negative impact on ethnocentrism. The ethnocentric attitudes of residents were significantly related to the positive and negative outcomes of tourism. Recommendations are provided for addressing problems related to cultural differences and regional cooperation for better understanding, tolerance, and social interactions between people living in the countries of Central Asia. This study contributes to the academic literature by integrating ethnocentrism and its antecedents with positive and negative outcomes of cultural tourism. It is of value to tourism practitioners and local policy makers in the Silk Road countries.
\end{abstract}

\section{Keywords}

impacts of tourism, patriotism, cultural openness, Central Asia

JEL Classification

L83, Z32, Q26

\section{INTRODUCTION}

In the past decades prior to COVID-19, tourism has experienced continued growth. The rise of technological advances and globalization have led to cheaper airfares, easier planning and booking travel, and sharing tourists' experiences with friends in real time (OECD, 2018). Global tourism has been growing from about 25 million international travelers in 1950 to 935 million in 2010, 1.5 billion in 2019 and was expected to be 1.6 billion in 2020 (UNWTO, 2009). Starting from 1970s, tourism industry experts started understanding that more and more people travel specifically to gain a deeper understanding of the culture or heritage of a destination. In 1990s, international cultural tourism has developed into mass market strategy with 35 to 70 percent of travelers being cultural tourists. More and more destinations have begun promoting their cultural and heritage assets. The situation has changed in 2020 . With a sharp decline in the number of international tourists, the tourism industry has suffered significantly since the COVID-19 outbreak (Polyakov et al., 2020; Ugur \& Akbiyik, 2020; Zenker \& Kock, 2020). However, while the number of international tourists is declining, there is still a potential for regional and local tourism. 
Ever after the concept of Silk Road tourism was first raised at the General Assembly of the World Tourism Organization in Indonesia in 1993 (UNWTO, 1993), UNWTO has been able to redefine the Silk Road by maximizing the benefits of tourism development for local communities and promotion of conservation of natural and cultural heritage (UNWTO, 2019). As the Silk Road has a long-standing and ongoing legacy of connecting people and cultures along its routes, there is a great potential to develop regional tourism across neigboring countries even under COVID situation (Rybina \& Lee, 2021). The trend for cultural and heritage tourism is growing as more and more travelers are interested in the past and culture of the others. From this perspective, the Great Silk Road is of high potential for the cultural and heritage tourism development. Despite historical trade relationships on the Silk Road caravan route, the changes in geopolitical and socio-cultural factors shape the individual attitudes and perceptions of people living in Eastern and Western Eurasia, in particular patriotism, cultural openness, and ethnocentrism. With tourism being viewed as an industry contributing to improved relationships between cultures by facilitating mutual understanding, there is insufficient literature with empirical evidence addressing this issue. Therefore, the main problem addressed in this study is related to the impact of endocentric attitudes of local residents on positive and negative outcomes of tourism in the context of cultural tourism along the Silk Road in the Central Asian countries.

\section{LITERATURE REVIEW AND HYPOTHESES DEVELOPMENT}

Cultural and heritage tourism overlap to a great extent: the content is the same, but the context is different. Cultural tourism often refers to individuals' visiting living cultures, contemporary art and music, and other elements of the modern culture, while heritage tourism can be defined as people visiting heritage places or viewing historical resources. Blended together cultural and heritage tourism "encompasses built patrimony, living styles, ancient artifacts and modern art and culture" (Timothy, 2011, p. 6). The literature (Ashworth \& Tunbridge, 2000; Chhabra, 2008; OECD, 2018; Timothy, 2011; Timothy \& Boyd, 2003) outlines the major trends affecting cultural tourism, such as growing demand for cultural tourism, increasing competition, growing demand for authenticity, ethical consumption and volunteering, heritage economics, multiculturism, and positive and negative impacts of tourism. Many countries, especially developing ones, are mostly concerned with positive impacts of tourism, with economic benefits obtained by the host people, and are unaware or overoptimistic about negative effects (Junaid \& d'Hauteserre, 2017; Fernandes, 2013). A range of positive and negative impacts of tourism may also occur in a destination (Handriana \& Ambara, 2016). In a range of studies on outcomes of the social contact (e.g. Andereck et al., 2005; Rasoolimanesh et al., 2017), some researchers argue that social contact between people from different cultures leads to better understanding and attitudes, respect, tolerance, mutual appreciation, improves social interactions between people (e.g. Bochner, 1982). The social contact also reduces ethnic stereotypes, prejudices, and racial tension, contributing to cultural enrichment and learning about other cultures (e.g. Robinson \& Preston, 1976). Whereas other studies on intercultural and cross-cultural social contact indicate negative attitudes, prejudices, hostility, suspicion, tension, conflict, disharmonies, and even violent attacks (e.g. Feather, 1980; Tajfel, 1969). In the tourism context, it was argued that the tourist-host contact is the most superficial form of cultural encounter (Hofstede, 1997), however, the contact and knowledge of each other culture is an important element on tourism. Social contact between tourists and hosts leads to better attitudes, understanding, cultural enrichment, and learning about others (Bochner, 1982). When tourists are respectful and showing interest in local culture, hosts have the pride of their culture and socialize more with tourists. However, when tourists and hosts come from very different cultures, there might be conflict of values. Often tourists would encounter situations unfamiliar to them, thus they do not know how to behave appropriately. The main challenges in cross-cultural interactions are verbal and non-verbal interpersonal communications and social behavior (Reisinger, 2009). The difficulties in verbal communications 


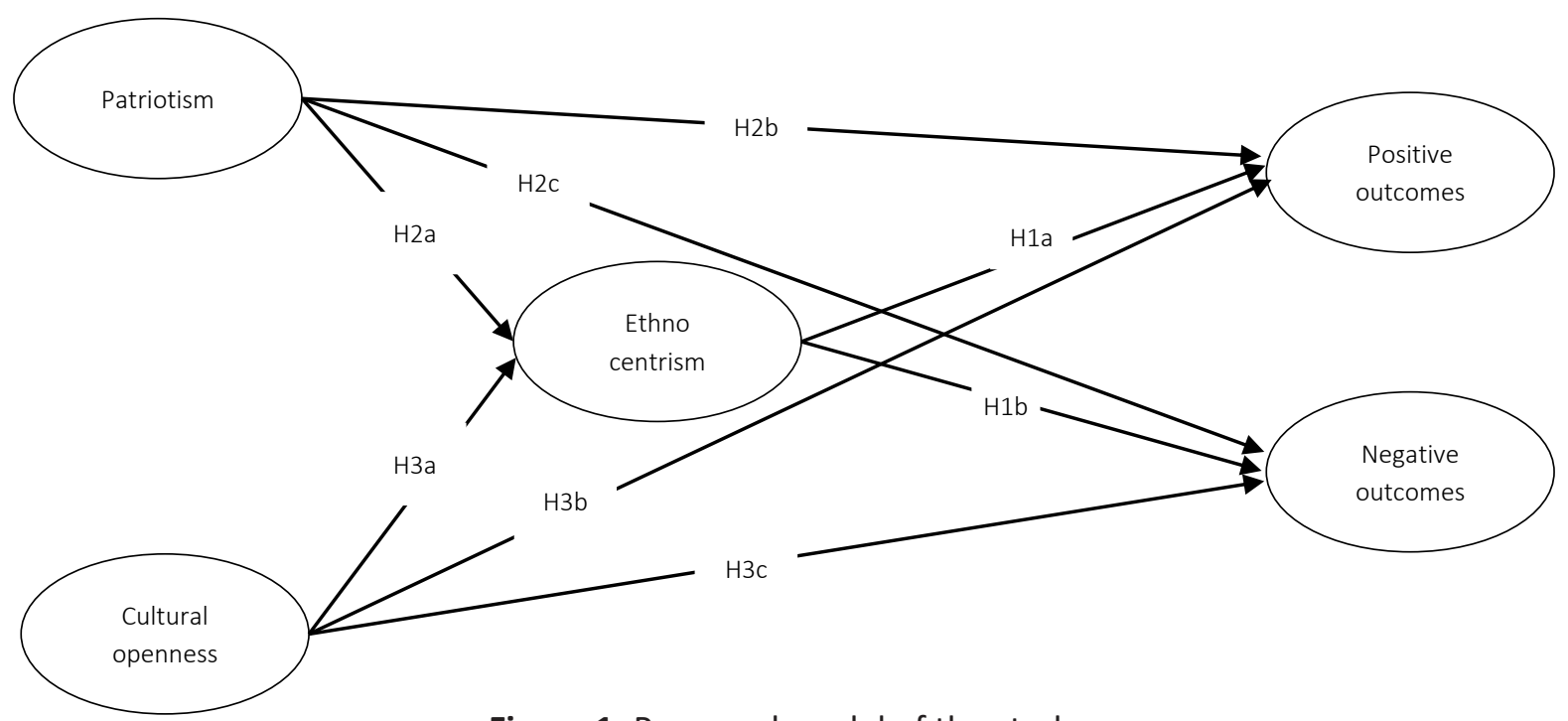

Figure 1. Proposed model of the study

come from different languages and overall verbal skills. The difficulties in non-verbal communication come from differences in non-verbal skills, such as body language, facial expressions, and spatial zones. The challenges in social behavior come from differences in social rules, such as greeting, thanking, or etiquette. All those difficulties can be reduced or even eliminated when both tourists and hosts are familiar of the differences and try to understand them. In the context of tourism, the sociographic and psychographic characteristics of both hosts and tourists can influence the social contact. Specifically, ethnocentrism can influence on how people perceive the impacts of tourism.

The concept of consumer ethnocentrism has been widely used in academic research to better understand consumer behavior (Alsughayir, 2013). Consumer ethnocentricity can be defined as consumer beliefs about the appropriateness, and in fact morality, of buying foreign-made products (Shimp \& Sharma, 1987) and "ethnocentrism gives the individual a sense of identity, feelings of belongingness, and an understanding of what purchase behavior is acceptable or unacceptable to the group" (p. 280). More recently ethnocentrism was applied to tourism and humanities studies (Kachhap \& Aravind, 2018). The results of the study of tourism ethnocentrism and its influence on the behavior of tourists and residents indicate the importance of studying the relationship of ethnocentrism with both tourists' and residents' behavior, since it stimulates the willingness of tourists to engage in tourism, as well as residents' support for the development of domestic tourism (Kock, Josiassen, Assaf, Karpen, \& Farrelly, 2019). The concept of ethnocentrism can be applied to cultural studies and in particular positive and negative outcomes of tourism.

Thus, the following hypotheses are proposed:

H1a: Ethnocentric attitudes of residents are related to positive outcomes of tourism.

H1b: Ethnocentric attitudes of residents are related to negative outcomes of tourism.

The literature states patriotism and openness to foreign cultures as antecedents of consumer ethnocentrism (Shankarmahesh, 2006; Sharma, 2015; Tantray, 2018). Sharma et al. (1995) expanded on their original work on measuring consumer ethnocentrism by adding new constructs of patriotism and openness to foreign cultures, which were added to the model as antecedents to individual ethnocentricity. In general terms, patriotism is the love for or devotion to one's country (Shah \& Halim, 2011). Cultural openness implies a passive exposure and acceptance and no rejection of foreign culture and people (Sharma et al., 1995). Patriotism was found to have a positive effect on ethnocentrism, while cultural openness has an adverse effect on consumer ethnocentrism (Alsughayir, 2013). Thus, it is hypothesized that:

H2a: Patriotism is related to ethnocentricity of residents. 
H2b: Patriotism is related to positive outcomes of tourism.

H2c: Patriotism is related to negative outcomes of tourism.

H3a: Cultural openness is related to ethnocentricity of residents.

H3b: Cultural openness is related to positive outcomes of tourism.

H3c: Cultural openness is related to negative outcomes of tourism.

Based on the aim of this study, which is to examine the relationship between patriotism, cultural openness, ethnocentrism, and positive and negative outcomes of tourism in the context of cultural tourism along the Silk Road in the Central Asian countries, the proposed model is presented in Figure 1.

\section{METHODS}

\subsection{Description of the study area}

"Silk Road" is a relatively recent term as majority of ancient roads had no particular name in their long history. UNESCO Silk Roads Project provides an inventory of the major cities along these routes and a brief description of their history and importance in the development of the Silk Roads. The selection of the study area was first based on the review of the Silk Routes passing the states in Cenral Asia and cultural heritage themes displayed on the UNESCO Silk Roads platform (UNESCO, 2019).

Two countries - Kazakhstan and Uzbekistan produced similar themes. Kazakstan has three cultiral sites listed, namely Mausoleum of Khoja Ahmed Yasawi, Petroglyphs within the Archaeological Landscape of Tamgaly, and Silk Roads: the Routes Network of Chang'an-Tianshan Corridor, while Uzbekistan has four cultural sites listed, specifically Itchan Kala, Historic Centre of Bukhara, Historic Centre of Shakhrisyabz, and Samarkand (UNESCO World Heritage List, 2019). Based on the review of cities considering Silk Road cultural heritage, location, population, three cit- ies were selected for the data collection, namely Turkestan (Kazakhstan), Burhara and Samarkand (Uzbekistan).

\subsection{Methodology}

The study uses quantitative survey approach to test hypothesized relationships between Patriotism, Cultural Openness, Ethnocentrism, and Positive and Negative Outcomes of tourism among residents of cultural tourism sites along the Silk Road. The construct measures for this research were adapted from the past studies (Keillor et al., 1996; Kim et al., 2015; Shimp \& Sharma, 1987; Yoon et al., 1996). The scale items were double translated and further modified after a pilot test. In the process of translation and adaptation of the scale items, the guidelines for conducting international consumer research by Craig and Douglas (2006) were followed. Five-point Likert-type scales $(1=$ strongly agree to $5=$ strongly disagree) were utilized for the individual scales to measure the constructs. The main part of the questionnaire consisted of six items of the scale for Ethnocentrisms, four items for Patriotism, four items for Cultural Openness, eleven items for Positive and eight items for Negative Impacts of tourism followed by a section with demographic questions.

The sample unit for this study was local residents living in the areas where heritage sites are located. Maximum variation purposive sampling and systematic sampling methods were applied to collect data among residents. The respondents were selected to ensure representation in terms of gender, age, and residence. The trained research assistants distributed pen and paper questionnaires in public areas of three cities where the world cultural heritage sites were located - Turkestan (Kazakhstan), Burhara and Samarkand (Uzbekistan). A small souvenir (pen) was offered to the respondents as a token of appreciation for participation in the survey. Data analysis included descriptive statistics, confirmatory factor analysis (CFA), and structural equation modeling (SEM) analysis.

\section{RESULTS}

About one hundred questionnaires were distributed in each city selected for this study. The incomplete questionnaires were excluded. After clean- 
Table 1. Sample characteristics $(n=146)$

\begin{tabular}{|c|c|c|}
\hline \multirow{2}{*}{ Gender } & Male & $38.4 \%(56)$ \\
\hline & Female & $61.6 \%(90)$ \\
\hline \multirow{4}{*}{ Age } & Younger than 30 & $34.2 \%(50)$ \\
\hline & 31 to 40 years old & $23.9 \%(35)$ \\
\hline & 41 to 50 years old & $22.6 \%(33)$ \\
\hline & Older than 50 & $19.2 \%(28)$ \\
\hline \multirow{3}{*}{ Income } & Below average & $35.6 \%(52)$ \\
\hline & Average & $49.3 \%(72)$ \\
\hline & Above average & $15.1 \%(22)$ \\
\hline
\end{tabular}

ing, only 146 questionnaires were used for further analysis. The sample was represented by $61.6 \%$ females and $38.4 \%$ males. Age groups included $34.2 \%$ of respondents of 18 to 30 years old, $23.9 \%$ of 31 to 40 years old, $22.6 \%$ of 41 to 50 years old, and $19.2 \%$ of 51 and more years old. The self-reported income level was distributed as $49.3 \%$ average, $15.1 \%$ above the average, and $35.6 \%$ below the average. The sample characteristics are presented in Table 1.

As the measurement constructs were based on the existing scales, a CFA was applied to confirm the factor structure and assess the fit of the measures as suggested in the literature (Kline, 2011). The initial model that included all items of the scales produced poor fit indices. Therefore, four items associated with the highest residuals and modification indices were excluded (see Table 2). The modified model produced acceptable overall fit. The Chi-Squared statistic is significant (Chi-Squared $712.79, \mathrm{df}=389, \mathrm{CMIN} / \mathrm{DF}=1.83)$. The RMSEA of 0.076 is below the 0.08 cut-off values (Kline, 2011). Overall, most of the fit indices are acceptable (CFI $=0.925, \mathrm{IFI}=0.926, \mathrm{NFI}=0.851$, and TLI $=0.917$ ).

Table 2. Confirmatory factor analysis results

\begin{tabular}{|c|c|}
\hline Construct/Items & Loading \\
\hline \multicolumn{2}{|l|}{ Patriotism } \\
\hline Being a citizen of my country means a lot to me & 0.98 \\
\hline I am proud to be a citizen of my country & 0.83 \\
\hline $\begin{array}{l}\text { When a foreign person praises my country, it feels } \\
\text { like a personal compliment }\end{array}$ & 1.00 \\
\hline I feel strong ties with my country & 0.72 \\
\hline \multicolumn{2}{|l|}{ Cultural openness } \\
\hline $\begin{array}{l}\text { I like immersing myself in different cultural } \\
\text { environments }\end{array}$ & 0.90 \\
\hline $\begin{array}{l}\text { I like having contact with people from different } \\
\text { cultures }\end{array}$ & 0.78 \\
\hline $\begin{array}{l}\text { I would enjoy travelling to foreign countries for an } \\
\text { extended period of time }\end{array}$ & 1.00 \\
\hline $\begin{array}{l}\text { Getting information and news from around the world } \\
\text { is important to me }\end{array}$ & 0.92 \\
\hline
\end{tabular}

\begin{tabular}{l|c}
\hline \multicolumn{1}{c}{ Construct/Items } & Loading \\
\hline \multicolumn{1}{c}{ Ethnocentrism } & \\
\hline $\begin{array}{l}\text { Products and services made in my country, first, last } \\
\text { and foremost }\end{array}$ & 0.95 \\
\hline $\begin{array}{l}\text { A real citizen of my country should always buy local } \\
\text { products and services }\end{array}$ & 0.94 \\
\hline $\begin{array}{l}\text { Citizens of my country should not buy foreign } \\
\text { products, because this hurts the business and causes } \\
\text { unemployment in my country }\end{array}$ & 0.99 \\
$\begin{array}{l}\text { It may cost me in the long run, but................................................. } \\
\text { domestic products and services }\end{array}$ & 1.00 \\
$\begin{array}{l}\text { Consumers who purchase products ma.................................... } \\
\text { countries are responsible for putting their fellow } \\
\text { citizens out of work }\end{array}$ & 0.90 \\
$\begin{array}{l}\text { Only those products that are unava..................................................... } \\
\text { country should be imported }\end{array}$ & $*$ \\
\hline
\end{tabular}

\section{Positive outcomes}

Increased leisure facilities

Increased community development investments

Provided an incentive for the preservation of the local culture

Enhanced the community pride of local residents

Enhanced the sense of being a part of community

Improved the image of the county

Reinforced community spirit

Increased trade for local business

Improved economic conditions

Increased the understanding of the other cultures

and societies of visitors

Increased interest in tourism

\section{Negative outcomes}

Increased road closures/disruption

Resulted in traffic congestion

Increased hardship for finding parking spaces

Increased risk of terrorism (e.g., bomb threat)

$*$
$*$
$*$
$*$

0.89

0.98

1.00

0.99

0.90

0.94

0.91

0.99

Increased disturbance from visitors (e.g., hooligans,

disorder, and vandalism)

Excessive spending on new infrastructure for the

event

Excessive spending for building tourism attractions

Local residents were not a primary consideration for

the tourism operators

0.94

1.00

0.89

0.95

0.91

0.90

0.92

0.90

Note: * Items associated with the highest residuals and modification indices were excluded.

The results of the SEM are presented in Table 3. All hypotheses stated for this study were supported with p-values of less than 0.01 . Patriotism 
Table 3. Hypotheses testing results

\begin{tabular}{|c|c|c|c|}
\hline Hypotheses & Linkage & Est ( $p$-value) & Result \\
\hline H1a: & Ethnocentrism $\rightarrow$ Positive Outcomes $(-)$ & $-0.41(<0.001)$ & Supported \\
\hline H1b: & Ethnocentrism $\rightarrow$ Negative Outcomes $(+)$ & $0.38(<0.001)$ & Supported \\
\hline H2a: & Patriotism $\rightarrow$ Ethnocentrism $(+)$ & $0.58(<0.001)$ & Supported \\
\hline $\mathrm{H} 2 \mathrm{~b}$ : & Patriotism $\rightarrow$ Positive Outcomes (-) & $-0.33(<0.001)$ & Supported \\
\hline H2c: & Patriotism $\rightarrow$ Negative Outcomes (+) & $0.28(0.009)$ & Supported \\
\hline H3a: & Cultural Openness $\rightarrow$ Ethnocentrism (-) & $-0.31(<0.001)$ & Supported \\
\hline H3b: & Cultural Openness $\rightarrow$ Positive Outcomes $(+)$ & $0.21(0.006)$ & Supported \\
\hline H3c: & Cultural Openness $\rightarrow$ Negative Outcomes (-) & $-0.24(0.007)$ & Supported \\
\hline
\end{tabular}

Table 4. Mean comparison for constructs

\begin{tabular}{|c|c|c|}
\hline Construct & Mean* & Std. deviation \\
\hline Patriotism & 3.36 & 0.79 \\
\hline Cultural openness & 2.56 & 0.84 \\
\hline Ethnocentrism & 3.34 & 0.86 \\
\hline Positive outcomes & 3.49 & 0.79 \\
\hline Negative outcomes & 2.50 & 0.83 \\
\hline
\end{tabular}

Note: * Based on five-point Likert-type scales ( 1 = strongly agree to $5=$ strongly disagree).

was found to have a statistically significant positive impact on ethnocentrism of local residents, while cultural openness had a significant negative impact on ethnocentrism. These findings support the past studies on antecedents of consumer ethnocentrism (Alsughayir, 2013). The ethnocentric attitudes of residents were significantly related to the positive and negative outcomes of tourism, which supports the findings of the past studies indicating residents' support for domestic tourism development for ethnocentric residents (Kock et al., 2019). Higher ethnocentric attitudes lead to more negative perceptions of tourism impacts among residents of the cultural tourism sites and to lower perceptions of positive impacts. The analysis of the relationship between the antecedents of ethnocentrism and impacts of tourism revealed that both patriotism and cultural openness are sig- nificantly related to positive and negative outcomes of tourism.

The one sample $t$-test and analysis of means for main constructs for this study (see mean and standard deviation values in Table 4) indicated that cultural openness of local residents is significantly higher than their patriotism attitudes. Thus, even with patriotism leading to more negative and less positive impacts of tourism, the cultural openness of local people contributes to higher perceptions of positive and lower perceptions of negative outcomes of tourism. Overall, residents perceive tourism outcomes being more negative than positive ( $p$-value $<0.05)$. The findings of this study in the context of cultural tourism support the previous research across various fields about patriotism and cultural openness as antecedents of consumer ethnocentrism (e.g. Alsughayir, 2013; Kock et al., 2019).

\section{CONCLUSION}

This study integrates ethnocentrism of local residents and its antecedents with positive and negative impacts of cultural tourism in the context of the Central Asia. Based on the findings of this study, the major conclusions can be drawn that residents with high patriotic and ethnocentric attitudes have higher perceptions of negatives outcomes and lower perceptions of positive outcomes of the cultural tourism in the region, while more culturally open residents have higher perceptions of positive and lower perceptions of negative outcomes of tourism. 
The novelty of this study is in proposing an integrated model of ethnocentrism and its antecedents (patriotism and cultural openness) with positive and negative outcomes of cultural tourism and testing this model in the context of the Central Asia. The study is of value to local policymakers and practitioners of tourism. Besides, with the effects of the recent economic recession due to the COVID-19 crisis, this study calls for more active support for the tourism industry.

A set of recommendations can be drawn regarding heritage and cultural tourism along the Silk Road. First of all, all parties involved in the delivery of tourism services should be aware of the possible positive and negative impacts of tourism both on tourists and especially on local communities. Learning and understanding of each other's cultures is vital for successful heritage and cultural tourism. Effective management of tourism destinations is important to control the impacts of tourism.

The study has some limitations. Only residents of selected cultural and heritage sites in two countries were surveyed. Future research could address positive and negative impacts from the perspective of other important stakeholders such as the domestic tourism industry, foreign tourists, government and local authorities. A cross-country comparison could also generate additional insights.

\section{AUTHOR CONTRIBUTIONS}

Conceptualization: Liza Rybina.

Data curation: Liza Rybina.

Formal analysis: Liza Rybina.

Funding acquisition: Liza Rybina.

Investigation: Liza Rybina.

Methodology: Liza Rybina.

Project administration: Liza Rybina.

Resources: Liza Rybina.

Software: Liza Rybina.

Supervision: Liza Rybina.

Validation: Liza Rybina.

Visualization: Liza Rybina.

Writing - original draft: Liza Rybina.

Writing - review \& editing: Liza Rybina.

\section{REFERENCES}

1. Alsughayir, A. (2013). Consumer Ethnocentrism: A Literature Review. International Journal of Business and Management Invention, 2(5), 50-54. Retrieved from https://www.researchgate.net/ publication/284024917_Consumer_ethnocentrism_A_literature review

2. Andereck, K. L., Valentine, K. M., Anshell, M., Knopf, R. C., \& Vogt, C. A. (2005). Residents' Perceptions of Community Tourism Impacts. Annals of Tourism Research, 32(4), 1056-1076. Retrieved from https://www.researchgate.net/ publication/222240098_Resi-
dents'_Perceptions_of_Community_Tourism_Impacts

3. Ashworth, G., \& Tunbridge, J. (2000). The Tourism-historic City. Amsterdam: Pergamon.

4. Bochner, S. (1982). Cultures in Contact: Studies in Cross-Cultural Interaction. Oxford, New York: Pergamon Press.

5. Chhabra, D. (2008). Sustainable Marketing of Cultural and Heritage Tourism. London and New York: Routledge Taylor \& Francis Group.

6. Craig, C. S., \& Douglas, S. P. (2006). Beyond national culture: Implications of cultural dynamics for consumer research. International Marketing Review, 23(3), 322-342. https://doi. org/10.1108/02651330610670479

7. Feather, N. T. (1980). The study of values. Journal of Asia-Pacific and World Perspectives, 3, 3-13.

8. Fernandes, C. (2013). The impacts of cultural tourism on host communities. In R. Raj, K. Griffin, \& N. Morpeth (Eds), Cultural Tourism (pp. 26-39). Boston: CABI.

9. Handriana, T., \& Ambara, R. (2016). Responsible environmental behavior intention of travelers on ecotourism sites. Tourism and 
Hospitality Management, 22(2), 135-150. Retrieved from https:// pdfs.semanticscholar.org/f83e/4 277b8c4c80d86065365a402c41f 6c200191.pdf

10. Hofstede, G. (1997). Cultures and Organizations. Software of the Mind. New York: McGraw-Hill International.

11. Junaid, I., \& d'Hauteserre, A. M. (2017). Collaborative schemes for anticipating negative impacts of the tourists' visit. Tourism and Hospitality Management, 23(2), 279-294. https://doi.org/10.20867/ thm.23.2.8

12. Kachhap, B. M., \& Aravind, A. (2018). Revisiting Ethno-nationalism: A Study of Nihal De Silva's The Road from Elephant Pass. Rupkatha Journal on Interdisciplinary Studies in Humanities, 10(1), 37-47. https://doi.org/10.21659/ rupkatha.v10n1.05

13. Kim, W., Jun, H. M., Walke, M., \& Drane, D. (2015). Evaluating the perceived social impacts of hosting large-scale sport tourism events: Scale development and validation. Tourism Management, 48, 21-32. https://doi.org/10.1016/j. tourman.2014.10.015

14. Kline, R. B. (2011). Principles and Practice of Structural Equation Modeling. New York: Guilford.

15. Kock, F., Josiassen, A., Assaf, A. G., Karpen, I., \& Farrelly, F. (2019). Tourism Ethnocentrism and Its Effects on Tourist and Resident Behavior. Journal of Travel Research, 58(3), 427-439. https://doi. org/10.1177/0047287518755504

16. OECD, (2018). Megatrends shaping the future of tourism, in OECD Tourism Trends and Policies 2018. Paris: OECD Publishing. https:// doi.org/10.1787/tour-2018-6-en

17. Polyakov, M., Bilozubenko, V., Nebaba, N., Korneyev, \& Saihak, Y. (2020). Analysis of asymmetry factors in the development of the EU tourism industry. Innovative Marketing, 16(4), 117-128. https://doi. org/10.21511/im.16(4).2020.10

18. Postma, A., \& Schmuecker, D. (2017). Understanding and overcoming negative impacts of tourism in city destinations: conceptual model and strategic framework. Journal of Tourism Futures, 3(2), 144-156. https://doi. org/10.1108/JTF-04-2017-0022

19. Rasoolimanesh, S. M., Roldan, J. L., Jaafar, M., \& Ramayah, T. (2017). Factors influencing residents' perceptions toward tourism development: differences across rural and urban world heritage sites. Journal of Travel Research, 56(6), 760-775. Retrieved from https://journals.sagepub.com/doi/ abs/10.1177/0047287516662354

20. Reisinger, Y. (2009). International Tourism: Cultures and Behaviors. Oxford: Elsevier.

21. Rezaei, N. (2017). Resident perceptions toward tourism impacts in historic center of Yazd, Iran. Tourism Geographies, 19(5), 734755. https://doi.org/10.1080/14616 688.2017.1331261

22. Robinson, J., \& Preston, J. (1976). Equal status contact and modification of racial prejudice: reexamination of the contact hypothesis. Social Forces, 54, 911-924. Retrieved from https://www.jstor. org/stable/2576183?seq=1

23. Rybina, L. \& Lee, T.J. (2021). Traveler Motivation and Destination Loyalty: Visiting Sacred Places in Central Asia. Tourism and Hospitality, 2, 1-14. https://doi. org/10.3390/tourhosp2010001

24. Shah, K. A. M., \& Halim, H. A. (2011). The influence of demographic profiles on consumer animosity, consumer ethnocentrism and patriotism. International Journal of Current Research, 3(10), 200-208.

25. Shankarmahesh, M. N. (2006). Consumer ethnocentrism: An integrative review of its antecedents and consequences. International Marketing Review, 23(2), 146-172. https://doi. org/10.1108/02651330610660065

26. Sharma, P. (2015). Consumer ethnocentrism: Reconceptualization and cross-cultural Validation. Journal of International Business Studies, 46(3), 381-389. Retrieved from https://link.springer.com/ article/10.1057/jibs.2014.42
27. Sharma, S., Shimp, T., \& Shin, J. (1995). Consumer ethnocentrism, a test of antecedents and moderators. Journal of the Academy of Marketing Science, 23(1), 2637. Retrieved from https://link. springer.com/article/10.1007/ BF02894609

28. Tajfel, R. (1969). Social and cultural factors in perception. In G. Lindzey \& E. Aronson (Eds.), The Handbook of Social Psychology. Reading, MA: Addison-Wesley Publishing.

29. Tantray, S. (2018). Consumer Ethnocentrism in 21st Century: A Review and Research Agenda. Business and Economics Journal, 9(3), 1-12. https://doi.org/10.4172/21516219.1000368

30. Timothy, D. \& Boyd, S. (2003). Heritage Tourism. New York: Prentice Hall.

31. Timothy, D. (2011). Cultural and Heritage Tourism: An Introduction. New York: Chanel View Publications.

32. UBESCO World Heritage List. (2019). Retrieved from http://whc. unesco.org/en/list/

33. Ugur, N. G., \& Akbiyii, A. (2020). Impacts of COVID-19 on global tourism industry: A cross regional comparison. Tourism Management Perspectives, 36, 100744. https://doi.org/10.1016/j. tmp.2020.100744

34. UNESCO. (2019). The Silk Roads Programme. Retrieved from https://en.unesco.org/silkroad/

35. UNWTO. (2009). Tourism 2020 Vision. Madrid: World Tourism Organization.

36. Woosnam, K. M., Norman, W. C., \& Ying, T. (2009). Exploring the Theoretical Framework of Emotional Solidarity between Residents and Tourists. Journal of Travel Research, 48(2), 245-258. Retrieved from https://journals.sagepub.com/ doi/10.1177/0047287509332334

37. Zenker, S., \& Kock, F. (2020). The coronavirus pandemic - A critical discussion of a tourism research agenda. Tourism Management, 81, 104164. https://doi.org/10.1016/j. tourman.2020.104164 